\title{
CHARACTERISTICS OF NATURAL BACKGROUND RADIATION AT BSUIN AND EUL UNDERGROUND LABORATORIES
}

\author{
Katarzyna Szkliniarz* \\ August Chełkowski Institute of Physics, University of Silesia in Katowice, Chorzów, Poland
}

\begin{abstract}
Characterization of underground laboratories in terms of their natural radioactivity is necessary to determine the conditions that prevail there and plan using these sites for scientific research and other activities. The article compares natural background radiation in three underground laboratories located in the Baltic Sea region. The comparison includes measurements made in underground laboratories (in-situ) and detailed laboratory analyses of water and rock samples taken from these locations. Measurements were made by gamma, alpha spectroscopy, and LSC technique.
\end{abstract}

Keywords: Natural radiation, radioisotope concentration, underground laboratories

\section{INTRODUCTION}

Natural radioactivity surrounds us everywhere, and its intensity varies depending on where we are currently staying. There are also places where the level of natural radioactivity is very low. Such places can be underground laboratories (ULs), where, among other things, large physical experiments are carried out, which need a unique environment to study extremely rare events such as neutrinoless double beta decay or searching for dark matter [1]. Increasingly, underground locations are also used for other purposes such as biology research, plant breeding, tourism, tunnel construction, and many more. The task of the BSUIN (Baltic Sea Underground Innovation Network) [2] and EUL (Empowering Underground Laboratories Network Usage) [3] projects is to strengthen underground laboratories located in the Baltic Sea region to make them more accessible to their users.

Physics experiments searching for rare events are performed deep underground to get rid of the disturbing background reactions caused by secondary comic radiation (SCR). At the shallow depths of the Reiche Zeche mine in Germany the shielding against SCR is already a factor of about 500 while it is even 6 orders of magnitude for the deepest of the three installations, the Callio Lab in Finland. The shielding against SCR at the Polkowice-Sieroszowice mine in Poland is about 5 orders of magnitude. In order to be able to take full advantage of ULs the determination of its shielding against SCR and the level of natural radioactivity should be examined.
The paper compares natural radioactivity in three ULs of the BSUIN and EUL projects (Callio Lab (Finland), Reiche Zeche mine (Germany), and in the Polkowice-Sieroszowice mine belonging to the Conceptual Lab development co-ordinated by KGHM Cuprum R\&D centre (Poland)). The results include insitu measurements in underground locations (gammaray measurements and radon concentration in the air) and laboratory analysis of rock and water samples from underground laboratories taken.

\section{MATERIALS AND METHODS}

\subsection{In-situ measurements}

In-situ measurements were made in three underground locations. In the Reiche Zeche mine, Germany, at a depth of $150 \mathrm{~m}$ ( $410 \mathrm{~m}$ w.e.) in the server room (in the orthogneiss rock layer) [4]; at Callio Lab, Finland, at a depth of 1436 m (4100 m w.e.) in Lab 2 (at sulphide deposit in felsic volcanic bedrock) [5]; in the Polkowice-Sieroszowice mine, Poland, at a depth of $1014 \mathrm{~m}$ (2942 m w.e.) in excavation No. 3 near SW1 shaft (in the anhydrite layer) [6].

In-situ measurements included gamma-ray measurements and radon concentration in the air.

All in-situ gamma measurements at three underground laboratories were performed using the same method with the same equipment. The gammaray measurements were performed with the use of portable gamma-ray spectroscopy (GR4020, Canberra Ind., USA), HPGe detector (high purity germanium) with $40 \%$ relative detection efficiency, multi-channel

\footnotetext{
*katarzyna.szkliniarz@us.edu.pl
} 
analyzer (InSpector ${ }^{\mathrm{TM}}$ 2000), and special software packages (Genie ${ }^{\mathrm{TM}}$ 2000 v3.2.1). Before the measurements, energy calibration was performed using seven sealed radioactive sources and efficiency calibration using the geometry of the room/box with internal surface contamination, modeled in the Geometry Composer software (ISOCSTM software).

Measurements of radon concentration in the air were also made with the use of the same $\mathrm{RAD} 7$ radon monitor (Radonova instruments) in the tested locations.

During the measurements, the HPGe and RAD7 radon monitor were placed next to each other and were located not far (about 1-2 m) from the walls of the underground rooms under study. Gamma-ray measurements lasted about two days, while the measurement of radon was carried out in 1-hour cycles, also for about 2 days.

\subsection{Laboratory analysis of the water and rock samples}

For a deeper analysis of natural radiation in the underground laboratories, laboratory analysis of rock and water samples was also performed. These studies were carried out in a specialized laboratory for measuring low activities at the Institute of Physics, the University of Silesia in Katowice (Poland). Rock and water samples were taken from the same places where in-situ measurements were carried out.

Radioactivity in waters is a complex and widely studied process [7], related to, among other things, isotope solubility in waters, the geology of individual deposits, lithology, water permeability, and collector properties of the rock mass, and the supply of the rock mass by surface waters.

The tests included the determination of the concentrations of radioisotopes of uranium $\left({ }^{234,238} \mathrm{U}\right)$, radium $\left({ }^{226,228} \mathrm{Ra}\right)$, and potassium $\left({ }^{40} \mathrm{~K}\right)$.

The concentrations of uranium radioisotopes $(234,238 \mathrm{U})$ in the water and rock samples were measured using alpha spectroscopy (7401VR (Canberra-Packard) and Alpha Analyst ${ }^{\mathrm{TM}}$ (Mirion Technologies (Canberra, Inc., USA)). Before the measurements, appropriate chemical procedures [8] were used to generate an alpha source for spectrometric measurements. Additionally, in the first stage of rock samples, wet mineralization with the use of hot acids was performed.

The concentration of radium $\left({ }^{226,228} \mathrm{Ra}\right)$ radioisotopes in the water samples were tested using the liquid scintillator counter (LSC) technique (1414 WinSpectral $\alpha / \beta$ LSC (Wallac) and 1410 Tricarb $\alpha / \beta$ LSC). Also, a chemical procedure was performed prior to the measurements [9]. The time of measurement of water samples was one $h$ (once per day for one month until a secular equilibrium between ${ }^{226} \mathrm{Ra}$ and its daughters was reached).

The Minimum Detectable Activity (MDA) for water samples was: for $234,238 \mathrm{U}$ : $0.5 \mathrm{mBq} / \mathrm{l}$ (0.5 l initial sample volume, 2 days measurement time), for ${ }^{226} \mathrm{Ra}$ : $0.015 \mathrm{~Bq} / \mathrm{l}$ and for ${ }^{228} \mathrm{Ra}$ : $0.04 \mathrm{~Bq} / \mathrm{l}$ (1.5 l initial sample volume). The MDA was $0.4 \mathrm{mBq}$ per sample for uranium isotopes $\left({ }^{234,238} \mathrm{U}\right)$ in rock samples.

Concentrations of radium $(226,228 \mathrm{Ra})$ and potassium $\left(4^{\circ} \mathrm{K}\right)$ isotopes in rock samples were tested using gamma spectroscopy with a lead-shielded HPGe detector (relative efficiency 20\%) with an electrically powered cryostat. Before the measurements, the samples were adequately prepared (dried, crushed, ground, and stored in a Marinelli beakers (for one month to achieve the secular equilibrium in thorium and uranium series)).

The measurement time of the rock samples was from about 2 to 10 days, depending on the sample's activity.

\section{RESULTS AND DisCUSSIONS}

\subsection{In-situ measurements results}

The gamma radiation spectra were measured in the energy range from 7 to $3150 \mathrm{keV}$. Based on the registered spectra in underground locations, the following values were determined, among others: gamma-ray flux, effective dose rate, counts rate. A detailed description of the method together with the formulas based on which the gamma-ray flux and effective dose rate (that a person would be exposed in this radiation field) were determined can be found in the paper of K. Polaczek-Grelik et al., 2020 [5] and K. Szkliniarz et al., 2021 [6]. The results are presented in Table 1. Additionally, Fig. 1 compares the registered insitu gamma-ray spectra (rate of counts per second as a function of gamma-ray energy) with identified major visible peaks, in three ULs (Reiche Zeche mine (server room), Callio Lab (Lab2), and Polkowice-Sieroszowice mine (excavation No.3))

Table 1. Comparison of gamma-ray flux, effective dose rate (that a person would be exposed in this radiation field) and counts per second in three BSUIN and EUL ULs

\begin{tabular}{|l|c|c|c|}
\hline Underground laboratory & $\begin{array}{c}\text { Gamma- } \\
\text { ray flux } \\
{\left[\mathrm{cm}^{-2} \mathrm{~s}^{-1}\right]}\end{array}$ & $\begin{array}{c}\text { Effective dose } \\
\text { rate }[\mu \mathrm{Sv} / \mathrm{h}]\end{array}$ & $\begin{array}{c}\text { Counts } \\
\text { per } \\
\text { second } \\
{\left[\mathrm{s}^{-1}\right]}\end{array}$ \\
\hline Reiche Zeche [4] & $2.8(8)$ & $0.036(8)$ & $516.95(5)$ \\
Callio Lab [5] & $12.7(1.5)$ & $0.158(29)$ & $654.75(5)$ \\
Polkowice-Sieroszowice [6] & $0.64(20)$ & $0.008(1)$ & $216.12(7)$ \\
\hline
\end{tabular}

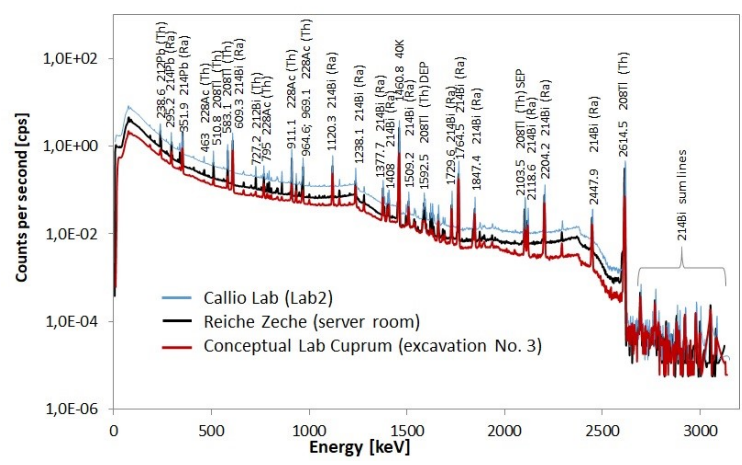

Figure 1. Comparison of in-situ gamma-ray spectra registered in three ULs of the BSUIN and EUL projects: Reiche Zeche mine (server room) at a depth of $150 \mathrm{~m}$ [4], Callio Lab (Lab 2) at a depth of $1436 \mathrm{~m}$ [5], and the Polkowice-Sieroszowice mine (excavation No. 3) at a depth of $1014 \mathrm{~m}$ [6]. The main visible peaks are identified.

The measured average radon concentration in the

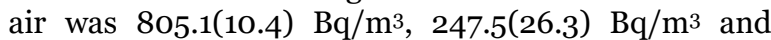
6.6(5.6) $\mathrm{Bq} / \mathrm{m}^{3}$ for Reiche Zeche mine, Callio Lab and Polkowice-Sieroszowice mine, respectively. 
The effective dose (to which people staying in UL are exposed) and gamma-ray flux at Callio Lab (Lab2) are four times higher than in the Reiche Zeche mine (server room) and 20 times higher than in the Polkowice-Sieroszowice mine (excavation No.3). At the same time, the counts' rates at Callio Lab (Lab2) are three times higher than at the Polkowice-Sieroszowice mine (excavation No. 3).

Based on the collected in-situ gamma-ray spectra, it can be concluded that among the three compared locations, Callio Lab has the highest level of natural radioactivity. The recorded spectra show summation lines in the energy area 2650-3150 keV and characteristic $\mathrm{X}$-rays for the bismuth and lead isotopes, proving the increased content of bismuth ${ }^{214} \mathrm{Bi}$ from the uranium isotope ${ }^{238} \mathrm{U}$ (the uranium series precursor) in the surrounding walls of the studied underground locations.

The lowest radon concentration in the air was measured in excavation No. 3 (Polkowice-Sieroszowice mine) and it is 120 times lower than in the server room (Reiche Zeche mine).

\subsection{Results of laboratory analysis of water and rock samples}

The comparison of the concentrations of radioisotopes of uranium $\left({ }^{234,238} \mathrm{U}\right)$ and radium $(226,228 \mathrm{Ra})$ in water samples in two underground laboratories (Reiche Zeche mine and Callio Lab) is presented in Table 2. The table does not include the results of water samples from the PolkowiceSieroszowice mine because the mine does not have any water sources.

Table 2. Comparison of the radioisotopes concentration $\left({ }^{234,238} \mathrm{U},{ }^{226,228} \mathrm{Ra}\right)$ in water samples from Reiche Zeche mine and Callio Lab.

\begin{tabular}{|l|l|l|}
\hline $\begin{array}{c}\text { Radioisotopes } \\
\text { concentration } \\
{[\mathrm{mBq} / \mathrm{l}]}\end{array}$ & $\begin{array}{c}\text { Reiche Zeche } \\
\text { mine [4] }\end{array}$ & \multicolumn{1}{|c|}{ Callio Lab [5] } \\
\hline${ }^{234 \mathrm{U}}$ & $142.4(4.9)$ & $0.8(2)-11.1(9)$ \\
$238 \mathrm{U}$ & $150.4(5.2)$ & $<0.5-6.5(7)$ \\
$226 \mathrm{Ra}$ & $<15$ & $15.1(4)-116.6(2.7)$ \\
$228 \mathrm{Ra}$ & $<40$ & $6.1(9)-36.9(2.1)$ \\
\hline
\end{tabular}

On the other hand, Table 3 compares the concentrations of uranium $(234,238 \mathrm{U})$, radium $\left({ }^{226,228} \mathrm{Ra}\right)$, and potassium $\left({ }^{\circ} \mathrm{K}\right)$ in rock samples in the three underground laboratories tested.

Table 3. Comparison of the radioisotopes concentration $\left.{ }^{234,238} \mathrm{U},{ }^{226,228} \mathrm{Ra},{ }^{\circ} \mathrm{K}\right)$ in rock samples from Reiche Zeche mine, Callio Lab and Polkowice-Sieroszowice mine.

\begin{tabular}{|l|l|l|l|}
\hline $\begin{array}{c}\text { Radioisotope } \\
\text { concentratio } \\
\mathrm{n} \\
{[\mathrm{Bq} / \mathrm{kg}]}\end{array}$ & $\begin{array}{c}\text { Reiche Zeche } \\
\text { mine [4] }\end{array}$ & Callio Lab [5] & $\begin{array}{l}\text { Polkowice- } \\
\text { Sieroszowice } \\
\text { mine [6] }\end{array}$ \\
\hline${ }^{234 \mathrm{U}}$ & $34.4(2.4)$ & $1.6(2)-10.3(1.3)$ & $8.7(3)$ \\
$238 \mathrm{U}$ & $32.4(2.3)$ & $1.4(2)-11.4(1.4)$ & $8.8(3)$ \\
$226 \mathrm{Ra}$ & $43.8(4)$ & $8.1(4)-58.0(2.3)$ & $7.2(3)$ \\
$228 \mathrm{Ra}$ & $31.5(6)$ & $2.6(3)-46.6(2.4)$ & $0.30(5)$ \\
$40 \mathrm{~K}$ & $1049(17)$ & $104(10)-272(24)$ & $9.4(3)$ \\
\hline
\end{tabular}

The highest concentrations of uranium radioisotopes were recorded in water samples from the Reiche Zeche mine. They were about 10 times higher for ${ }^{234} \mathrm{U}$ and about 20 times higher for ${ }^{238} \mathrm{U}$ than samples from Callio Lab. On the other hand, the concentrations of radium $\left({ }^{226,228} \mathrm{Ra}\right)$ radioisotopes in the water samples from the Reiche Zeche mine were below the detection limit.

Concentrations of uranium radioisotopes $(234,238 \mathrm{U})$ in rock samples in all ULs were at a similar level, which proving that a radioactive equilibrium between ${ }^{234} \mathrm{U}$ and ${ }^{238} \mathrm{U}$ was achieved (ratio ${ }^{234} \mathrm{U} /{ }^{238} \mathrm{U}$ about 1.0). The highest concentration of ${ }^{234} \mathrm{U}$ and ${ }^{238} \mathrm{U}$ was recorded in the samples from the Reiche Zeche mine and the lowest for the rock samples from Callio Lab. In turn, the lowest concentrations of radium $(226,228 \mathrm{Ra})$ and potassium $\left(4^{\circ} \mathrm{K}\right)$ radioisotopes were tested in anhydrite samples from the Polkowice-Sieroszowice mine. In the tested rock samples, a disequilibrium radioactive between the isotopes of uranium ${ }^{238} \mathrm{U}$ and radium ${ }^{226} \mathrm{Ra}$ from the uranium series can be noticed. The ${ }^{238} \mathrm{U} /{ }^{226} \mathrm{Ra}$ ratio below one was determined for the rock samples from the Reiche Zeche mine (0.7) and Callio Lab (from 0.07 to 0.7). In the samples taken from the Polkowice-Sieroszowice mine, this ratio was above one and was 1.2. This disequilibrium radioactive can be due to the difference in geochemical properties between radium $\left({ }^{226} \mathrm{Ra}\right)$ and uranium $\left({ }^{238} \mathrm{U}\right)$ and the greater mobility of radium in the environment.

In-situ gamma-ray measurements at Callio Lab and Reiche Zeche mine were made in rooms where the surrounding walls, floor, and ceiling were covered with concrete or bricks to stabilize the structure of the rooms [4,5]. Additionally, concrete samples were collected for Callio Lab for laboratory analysis (similar to rock samples). The uranium, radium, and potassium activities in concrete samples showed more significant activity (from 1 to 9 times) than for rock samples [5]. The increased concentration of the analyzed uranium series radioisotopes in the taken samples of concrete and rocks from Callio Lab and Reiche Zeche mine was confirmed by a higher level of gamma-ray in in-situ spectra.

\section{CONCLUSION}

Based on the presented comparison of three underground laboratories of the EUL and BSUIN projects (Callio Lab, Reiche Zeche mine, and Polkowice-Sieroszowice mine), it can be concluded that the lowest level of natural radioactivity was estimated in the anhydrite layer of the Polkowice-Sieroszowice mine. In combination with its very good shielding against SCR, although slightly worse than that of the Callio Lab, the Polkowice-Sieroszowice mine is very well suited for rare event experiments, like the search for neutrino-less double beta decay or other fundamental physics experiments.

Acknowledgements: The paper is a part of the research done within the Baltic Sea Underground Innovation Network (BSUIN) and Empowering Underground Laboratories Network Usage (EUL) founded by Interreg Baltic Sea Region.

\section{REFERENCES}

1. A. Bettini, "The world deep underground laboratories," Eur. Phys. J. Plus., vol. 127, no. 9, p. 114, Sep. 2012. DOI: 10.1140/epjp/i2012-12114-y 
2. Baltic Sea Underground Innovation Network (BSUIN), European Union, Brussels, Belgium.

Retrieved from:

https://bsuin.eu

Retrieved on: Jul. 25, 2021

3. European Underground Laboratories (EUL), European Union, Brussels, Belgium.

Retrieved from:

https://undergroundlabs.network/

Retrieved on: Jul. 25, 2021

4. K. Polaczek-Grelik et al., "Characterization of the radiation environment at TU Bergakademie in Freiberg, Saxony, Germany," Nucl. Instrum. Methods Phys. Res. $A$, vol. 946 , no. 8, 162652, Dec. 2019. DOI: 10.1016/j.nima.2019.162652

5. K. Polaczek-Grelik et al., "Natural background radiation at Lab 2 of Callio Lab, Pyhäsalmi mine in Finland," Nucl. Instrum. Methods Phys. Res. A, vol. 969, no. 9, 164015, Jul. 2020.

DOI: 10.1016/j.nima.2020.164015
6. K. Szkliniarz et al., "Characteristics of Natural Background Radiation in the Polkowice-Sieroszowice Mine, Poland," Energies, vol. 14, no. 14, 4261, Jul. 2021.

DOI: 10.3390/en14144261

7. A. Walencik-Łata, B. Kozłowska, T. A. Przylibski, "Hydrochemical behaviour of dissolved uranium in selected groundwaters of the Kłodzko Valley (SW Poland) and its application possibilities as an environmental tracer," Chemosphere, vol. 267, no. 1, 128911, Mar. 2021.

DOI: 10.1016/j.chemosphere.2020.128911 PMid: 33218734

8. J. Suomela, Method for Determination of U-Isotopes in Water, SSI report 93-14, Swedish Radiation Institute, Stockholm, Sweden, 1993.

9. Oznaczanie izotopów radu $w$ wodzie metoda LSC, Polska Norma PN-89/ZN-70072, 1989.

(Radium Isotopes Determination in Water with LSC Method, Polish Norm PN-89/ZN-70072, 1989.) 